\title{
Clostridium sulfidigenes sp. nov., a mesophilic, proteolytic, thiosulfate- and sulfur-reducing bacterium isolated from pond sediment
}

Correspondence

Alexander Steinbüchel

steinbu@uni-muenster.de

\section{Ahmed Sallam and Alexander Steinbüchel}

\author{
Institut für Molekulare Mikrobiologie und Biotechnologie, Westfälische Wilhelms-Universität \\ Münster, D-48149 Münster, Germany
}

While several Clostridium species are well known for their role in the nitrogen cycle as $\mathrm{N}_{2}$-fixing bacteria (Purushothaman et al., 1981), sulfide toxicity in several habitats such as rice-field soils has been attributed exclusively to sulfate-reducing bacteria that also reduce thiosulfate and sulfur. Thus, the establishment of the taxon Desulfotomaculum resulted in the reclassification of Clostridium nigrificans and a few other bacteria as members of this new genus, with the sulfate reducer Desulfotomaculum nigrificans (previously C. nigrificans) as the type species (Campbell \& Postgate, 1965). This led to the distinct definition of clostridia as being strictly anaerobic, Gram-positive, endospore formers that are unable to carry out dissimilatory sulfate reduction (Cato et al., 1986; Collins et al., 1994). However, some exceptional cases have also been reported, such as asporogenous mutants that may appear and proliferate, different degrees of aerotolerance

Abbreviation: CGP, cyanophycin.

The GenBank/EMBL/DDBJ accession number for the 16S rRNA gene sequence of strain SGB2 ${ }^{\top}$ is EF199998. known for several species and mesophilic clostridia that show a transient ability to reduce sulfate (Campbell \& Postgate, 1965; Hippe et al., 1992).

It was found recently that thiosulfate-reducing clostridia unable to reduce sulfate may also contribute to the formation of sulfide from inorganic sulfur compounds (Escoffier et al., 1998, 2001), e.g. the saccharolytic, thermophilic bacteria Clostridium thermohydrosulfuricum, Clostridium thermosaccharolyticum (Hollaus \& Sleytr, 1972) and Clostridium thermosulfurigenes (Schink \& Zeikus, 1983), which were subsequently reclassified and now belong to the genera Thermoanaerobacter and Thermoanaerobacterium (Lee et al., 1993). Only two mesophilic, proteolytic bacteria, Clostridium peptidivorans (Mechichi et al., 2000) and Clostridium thiosulfatireducens (Hernández-Eugenio et al., 2002), are able to reduce thiosulfate and are currently members of the genus Clostridium. In this study, an isolate belonging to the genus Clostridium, strain $\mathrm{SGB}^{\mathrm{T}}$, which is a strictly anaerobic, spore-forming bacterium isolated from an 
anaerobic consortium (pond sediment samples, Schloßgraben, Münster, Germany) as a member of a cyanophycin (CGP)-degrading consortium, is reported. The polymer CGP consists of equimolar amounts of aspartic acid and arginine (Simon \& Weathers, 1976) and functions as a temporary nitrogen, energy and possibly carbon reserve in cyanobacteria. CGP is degraded by intracellular cyanophycinases or by extracellular cyanophycinases of bacteria unable to synthesize CGP (Obst et al., 2005). Strain $\mathrm{SGB}^{\mathrm{T}}$ itself was unable to use CGP as a carbon and energy source, but occurred as a commensal micro-organism in the consortium and utilized CGP degradation products (Asp-Arg dipeptides) (Sallam \& Steinbüchel, 2008).

The enrichment of axenic cultures, DNA extraction and sequencing of the $16 \mathrm{~S}$ rRNA gene of strain $\mathrm{SGB}^{\mathrm{T}}$ were reported recently by Sallam \& Steinbüchel (2008). Accordingly, strain $\mathrm{SGB}^{\mathrm{T}}$ was assigned to the genus Clostridium, with Clostridium subterminale DSM $6970^{\mathrm{T}}$ and C. thiosulfatireducens $\operatorname{Lup} 21^{\mathrm{T}}$ as its closest phylogenetic relatives (99\% $16 \mathrm{~S}$ rRNA gene sequence similarity for both). However, analysis of the G+C content and DNADNA hybridizations (both performed at the DSMZ) showed that strain $\mathrm{SGB}^{\mathrm{T}}$ had a slightly higher $\mathrm{G}+\mathrm{C}$ content $(32.3 \mathrm{~mol} \%)$ than these two strains $(28 \mathrm{~mol} \%$ and $31.4 \mathrm{~mol} \%$, respectively) and DNA-DNA hybridization values were only 42.1 and $39.4 \%$, respectively, which indicated that strain $\mathrm{SGB}^{\mathrm{T}}$ is clearly not a strain of $C$. subterminale or C. thiosulfatireducens.

The next closest phylogenetic relative to strain $\mathrm{SGB}^{\mathrm{T}}$ was 'Clostridium tunisiense' DSM 15206 (96\% 16S rRNA gene sequence similarity), whereas $C$. peptidivorans $\mathrm{TMC}^{\mathrm{T}}$ showed much lower similarity to strain $\mathrm{SGB}^{\mathrm{T}}$ (93\%). Using only a trimmed part (1434 bp) of the $16 \mathrm{~S}$ rRNA gene sequence of strain $\mathrm{SGB}_{2}{ }^{\mathrm{T}}$ and the available sequences for related strains in the NCBI database, a phylogenetic tree was generated (Fig. 1). This tree shows the relationship between strain $\mathrm{SGB}^{\mathrm{T}}$, C. subterminale DSM $6970^{\mathrm{T}}$, the

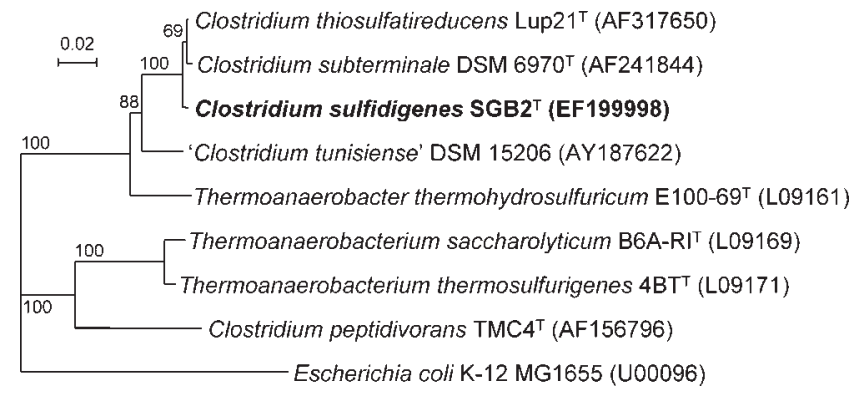

Fig. 1. Neighbour-joining tree based on 16S rRNA gene sequences showing the estimated phylogenetic relationships of Clostridium sulfidigenes sp. nov. $\mathrm{SGB}^{\top}$ and closely related species. Accession numbers are given in parentheses. Bootstrap values are shown as percentages of 100 replicates. Bar, $2 \%$ sequence divergence. sulfur-reducer ' $C$. tunisiense' DSM 15206 and related species reported to reduce thiosulfate. DNA G $+\mathrm{C}$ content analysis and the phylogenetic tree showed that strain $\mathrm{SGB} 2^{\mathrm{T}}$ is a member of the low-G +C-containing Grampositive bacteria and represents a member of cluster I of the order Clostridiales (Collins et al., 1994; Stackebrandt \& Rainey, 1997).

Growth studies were performed in duplicate under anaerobic conditions in Hungate tubes containing basal medium (Sallam \& Steinbüchel, 2008) with $0.5 \%(\mathrm{w} / \mathrm{v})$ proteose peptone (Difco) and were inoculated from similar precultures. Cells of strain $\mathrm{SGB}^{\mathrm{T}}$ multiplied only in an oxygen-free anaerobic atmosphere and at temperatures between 18 and $48{ }^{\circ} \mathrm{C}$, with optimum growth at $34{ }^{\circ} \mathrm{C}$, which is lower than its taxonomic relatives. Strain $\mathrm{SGB} 2^{\mathrm{T}}$ could grow at $\mathrm{pH}$ 5.5-9.0, with optimum growth at $\mathrm{pH}$ 6.6. Optimum growth occurred in the absence of $\mathrm{NaCl}$; however, retarded growth occurred up to an $\mathrm{NaCl}$ concentration of $20 \mathrm{~g} \mathrm{l}^{-1}$. Additionally, strain $\mathrm{SGB} 2^{\mathrm{T}}$ differed from its closest relatives in several other criteria including reduction of electron acceptors and the range of utilizable amino acids (Table 1).

C. thiosulfatireducens DSM $13105^{\mathrm{T}}$ and C. peptidivorans DSM $12505^{\mathrm{T}}$ were used as reference strains to investigate the use of inorganic electron acceptors by strain SGB2 ${ }^{\mathrm{T}}$. This was determined photometrically by the increase in growth (turbidity) and $\mathrm{H}_{2} \mathrm{~S}$ production as described by Sallam \& Steinbüchel (2008). Table 1 shows the characteristics of strain $\mathrm{SGB}^{\mathrm{T}}$ and other related strains regarding reduction of inorganic sulfur compounds. Notably, sulfate was not reduced by axenic cultures of strain $\mathrm{SGB}^{\mathrm{T}}$ except, non-reproducibly, in a few experimental repetitions (two of 18 independent repetitions) whereas, in co-cultivations with other isolates from the same mixed consortium, sulfate reduction by strain $\mathrm{SGB} 2^{\mathrm{T}}$ was stable over several repetitions (Sallam \& Steinbüchel, 2008). In contrast, growth of strain $\mathrm{SGB}_{2}^{\mathrm{T}}$ in the presence of thiosulfate consistently started after 1 day of incubation, yielding a maximum $\mathrm{OD}_{578}$ of 0.7 after 10 days and producing $2.6 \mathrm{mM} \mathrm{H}_{2} \mathrm{~S}$.

Growth and $\mathrm{H}_{2} \mathrm{~S}$ production by strain $\mathrm{SGB}^{\mathrm{T}}$ on the utilized substrates is shown in Fig. 2. The presence of thiosulfate improved substrate utilization as revealed by growth to higher OD, in particular on proteose peptone (Difco) $(22.8 \%)$, Casamino acids (10\%), trypticase soy (17.2\%), L-arginine $(21.5 \%)$, L-ornithine $(14.5 \%)$ and L-citrulline $(9.2 \%)$. Relatively large amounts of $\mathrm{H}_{2} \mathrm{~S}$ were produced in the presence of thiosulfate, especially on proteose peptone $(4.8 \mathrm{mM})$, Casamino acids $(3.8 \mathrm{mM})$, trypticase soy $(5.5 \mathrm{mM})$, gelatin $(8.0 \mathrm{mM})$, L-arginine $(4.0 \mathrm{mM})$, L-valine $(3.4 \mathrm{mM})$ and L-cysteine $(3.7 \mathrm{mM})$ (Fig. 2). In the absence of thiosulfate, only negligible $\mathrm{H}_{2} \mathrm{~S}$ production was observed.

Fermentation products of the utilized substrates were measured by HPLC (LaChrom Elite HPLC; VWR-Hitachi) as described by Sallam \& Steinbüchel (2008). The main 
Table 1. Comparison between the characteristics of strain $\mathrm{SGB}^{\top}$ and its closest phylogenetic relatives

Strains: 1, strain SGB2 ${ }^{\mathrm{T}}$ (data from this study); 2, C. subterminale DSM 6970 ${ }^{\mathrm{T}}$ (unless indicated, data from Elsden \& Hilton, 1979; Cato et al., 1986; Hippe et al., 1992); 3, C. thiosulfatireducens DSM $13105^{\mathrm{T}}$ (unless indicated, data from Hernández-Eugenio et al., 2002); 4, C. peptidivorans DSM $12505^{\mathrm{T}}$ (unless indicated, data from Mechichi et al., 2000); 5, 'C. tunisiense' DSM 15206 (data from Thabet et al., 2004). Studies on the utilization of electron acceptors and substrates were performed in liquid basal medium containing $0.5 \%$ (w/v) Casamino acids for electron acceptors, or $1 \mathrm{~g}$ yeast extract $1^{-1}, 20 \mathrm{mM}$ sodium thiosulfate and no cysteine for substrate utilization. The following concentrations were used in electron acceptor tests: $20 \mathrm{mM}$ sodium sulfate, $20 \mathrm{mM}$ sodium thiosulfate and $2 \%(\mathrm{w} / \mathrm{v})$ elemental sulfur. Substrate concentrations were: $10 \mathrm{mM}$ for amino acids, $5 \mathrm{~g} \mathrm{l}^{-1}$ for peptides and $20 \mathrm{mM}$ for carbohydrates and organic acids. All experiments were performed in Hungate tubes and incubated at $34{ }^{\circ} \mathrm{C}$ for at least 15 days. Additionally, L-proline, L-isoleucine, L-serine, peptone, Casamino acids, gelatin and CGP dipeptides were utilized by all strains. The following substrates were tested and were not utilized by any of the strains: lactose, glucose, galactose, mannose, arabinose, xylose, cellobiose, ribose, maltose, sucrose, fructose, lactate, acetate, succinate, ethanol, 1-propanol and CGP. ND, No data available.

\begin{tabular}{|c|c|c|c|c|c|}
\hline Characteristic & 1 & 2 & 3 & 4 & 5 \\
\hline Source & $\begin{array}{l}\text { Pond } \\
\text { sediment }\end{array}$ & $\begin{array}{l}\text { Human } \\
\text { infections }\end{array}$ & $\begin{array}{c}\text { Cheese factory } \\
\text { wastewater }\end{array}$ & $\begin{array}{l}\text { Olive mill } \\
\text { wastewater }\end{array}$ & $\begin{array}{l}\text { Olive mill } \\
\text { wastewater }\end{array}$ \\
\hline Range $\left({ }^{\circ} \mathrm{C}\right)$ & $18-48$ & $25-45$ & $18-45$ & $20-42$ & $18-43$ \\
\hline Optimum $\left({ }^{\circ} \mathrm{C}\right)$ & 34 & 37 & 37 & 37 & 37 \\
\hline \multicolumn{6}{|l|}{ Growth pH } \\
\hline Optimum & 6.6 & $7.5^{a_{\star}}$ & 7.4 & 7 & 7.8 \\
\hline \multicolumn{6}{|l|}{$\mathrm{NaCl}$ concentration for growth } \\
\hline Range ( $\left.\mathrm{g} \mathrm{l}^{-1}\right)$ & $0-20$ & $0-80$ & $0-60$ & $0-40$ & $0-30$ \\
\hline Optimum $\left(\mathrm{g} \mathrm{l}^{-1}\right)$ & 0 & $0-10$ & 0 & 0 & $0-15$ \\
\hline DNA G $+\mathrm{C}$ content $(\mathrm{mol} \%)$ & 32.3 & 28 & 31.4 & 31 & 32.6 \\
\hline Thiosulfate reduction & + & $-{ }^{b}$ & $+{ }^{c}$ & $+{ }^{c}$ & - \\
\hline L-Aspartate & - & ND & $-{ }^{c}$ & - & $\mathrm{ND}$ \\
\hline L-Arginine & + & + & $-{ }^{c}$ & + & $\mathrm{ND}$ \\
\hline L-Lysine & - & + & $+{ }^{c}$ & + & + \\
\hline L-Alanine & + & $+{ }^{a}$ & $+{ }^{c}$ & - & - \\
\hline L-Histidine & - & $+{ }^{a}$ & $+{ }^{c}$ & + & + \\
\hline L-Leucine & + & + & $+{ }^{c}$ & - & + \\
\hline L-Methionine & + & $+{ }^{a}$ & $+{ }^{c}$ & + & - \\
\hline L-Threonine & + & - & $+{ }^{c}$ & - & + \\
\hline L-Phenylalanine & + & + & $+{ }^{c}$ & - & $\mathrm{ND}$ \\
\hline L-Valine & + & + & $+{ }^{c}$ & - & + \\
\hline L-Cysteine & + & $\mathrm{ND}$ & $-{ }^{c}$ & + & + \\
\hline
\end{tabular}

${ }^{*}$ Data from: $a$, Thabet et al. (2004); b, Hernández-Eugenio et al. (2002); c, this study.

fermentation end-products from Casamino acids, trypticase soy and gelatin were acetate, propionate, valerate and butyrate. Peptone was converted mainly to acetate, succinate, propionate and valerate, whereas yeast extract was fermented to acetate and ethanol. The main fermentation end product detected from citrulline, ornithine, alanine, threonine, serine and cysteine was acetate. Utilization of arginine produced acetate and ethanol, whereas utilization of methionine and phenylalanine produced mainly propionate. Valine was converted to butyrate, leucine to valerate, and pyruvate to acetate and ethanol. 


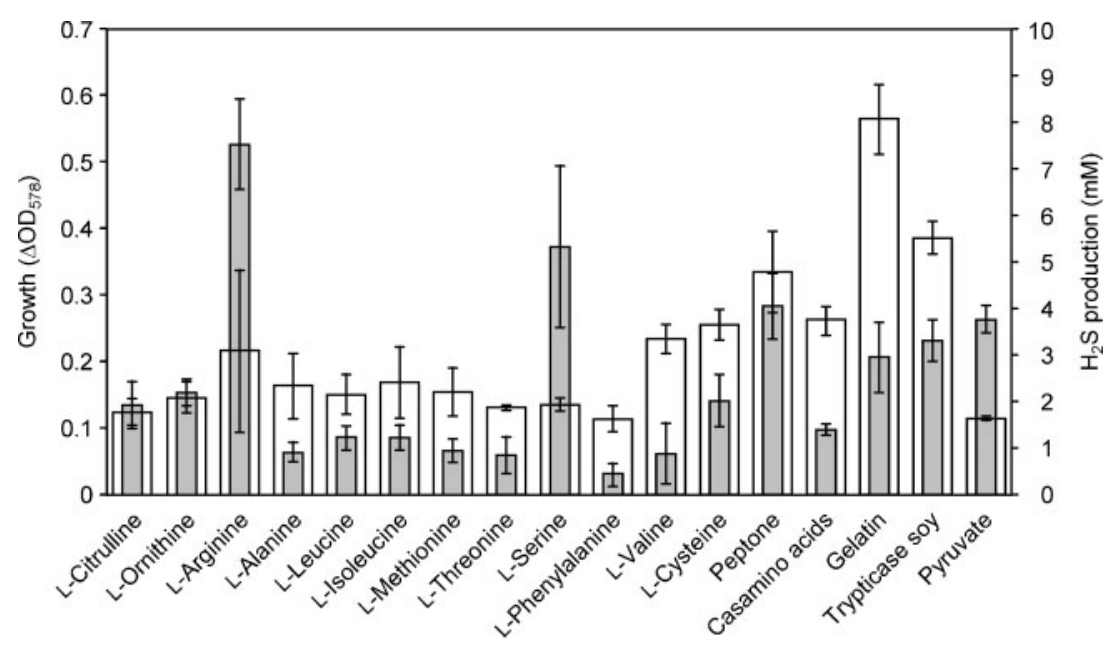

Fig. 2. Growth and $\mathrm{H}_{2} \mathrm{~S}$ production of strain $\mathrm{SGB}^{\top}$ in the presence of various substrates. Cultivation experiments were done in basal medium containing $1 \mathrm{~g}$ yeast extract $\mathrm{I}^{-1}$ and $20 \mathrm{mM}$ sodium thiosulfate, in addition to the indicated substrate at concentrations of $10 \mathrm{mM}$ for amino acids, $5 \mathrm{~g} \mathrm{I}^{-1}$ for peptides and $20 \mathrm{mM}$ for pyruvate, incubated at $34{ }^{\circ} \mathrm{C}$ for 6 days. Shaded bars show growth (change in $\mathrm{OD}_{578}$ compared with control tubes); open bars show $\mathrm{H}_{2} \mathrm{~S}$ production (mM). Data shown represent means and standard deviations from duplicate cultivation tubes.
Based on the phenotypic, genotypic and phylogenetic characteristics mentioned above and in Table 1, the novel isolate was designated the type strain of a novel species of the genus Clostridium; Clostridium sulfidigenes sp. nov. This study provides another example, in addition to previous observations, that strain $\mathrm{SGB}^{\mathrm{T}}$ and other proteolytic clostridium strains probably play a significant role in the sulfur cycle and in the degradation of peptides, proteins and amino acids in different environments. They are greatly affected by the presence of different forms of inorganic and organic sulfur compounds. In addition, the increasing number of reports on Clostridium species with such special traits extends the known diversity of this genus.

\section{Description of Clostridium sulfidigenes sp. nov.}

Clostridium sulfidigenes (sul.fi.di'ge.nes. N.L. n. sulfidum sulfide; N.L. neut. suff. -genes producing from Gr. v. gennaio to produce; N.L. neut. part. adj. sulfidigenes sulfide-producing).

Cells are rods, about 3-6 $\mu \mathrm{m}$ long and $0.5 \mu \mathrm{m}$ in diameter, occurring as single cells or in pairs, and are motile until sporulation. Subterminal to terminal spores are formed. Gram staining is positive. Colonies appearing after $48 \mathrm{~h}$ of incubation on peptone at $34{ }^{\circ} \mathrm{C}$ and after only $24 \mathrm{~h}$ on yeast extract are round with regular margins, translucent on peptone and yellowish brown on yeast extract. Optimum growth temperature is $34{ }^{\circ} \mathrm{C}$, with growth at $18-48{ }^{\circ} \mathrm{C}$. Optimum $\mathrm{pH}$ for growth is 6.6 and growth occurs at $\mathrm{pH}$ 5.5-9.0. Optimum growth occurs in the absence of NaCl; however, concentrations up to $20 \mathrm{~g} \mathrm{NaCl}$ $1^{-1}$ are tolerated. The following substrates are used as carbon and energy sources: peptone, Casamino acids, gelatin, trypticase soy, L-citrulline, L-ornithine, L-arginine, L-alanine, L-leucine, L-isoleucine, L-methionine, L-threonine, L-serine, L-phenylalanine, L-valine, L-cysteine and pyruvate. The following substrates are not used: L-proline, L-aspartate, L-lysine, L-histidine, L-glutamate, glycine, DLtryptophan, L-tyrosine, lactose, glucose, galactose, man- nose, arabinose, xylose, cellobiose, ribose, maltose, sucrose, fructose, lactate, acetate, succinate, ethanol and 1-propanol. The main fermentation end products from Casamino acids, trypticase soy and gelatin are acetate, propionate, valerate and butyrate. Peptone is converted mainly to acetate, succinate, propionate and valerate, whereas yeast extract is converted to acetate and ethanol. The main fermentation end product detected from citrulline, ornithine, alanine, threonine, serine and cysteine is acetate; from arginine utilization, end-products are acetate and ethanol, and from methionine and phenylalanine, the endproduct is mainly propionate. Valine is converted to butyrate, leucine to valerate, and pyruvate to acetate and ethanol. Uses thiosulfate and sulfur, but not sulfite, nitrate or nitrite as electron acceptors. Thiosulfate improves the utilization of proteose peptone (Difco), Casamino acids, trypticase soy, L-arginine, L-ornithine and L-citrulline.

The type strain is SGB2 ${ }^{\mathrm{T}}\left(=\right.$ DSM $18982^{\mathrm{T}}=$ ATCC BAA$\left.1538^{\mathrm{T}}\right)$, isolated from pond sediment in Münster, Germany. Adverse effects on humans and animals by strain $\mathrm{SGB}^{\mathrm{T}}$ are not known, but cannot be excluded. Cautious handling and autoclaving of cultures before disposal is recommended. Strain $\mathrm{SGB} 2^{\mathrm{T}}$ has a DNA G $+\mathrm{C}$ content of $32.3 \mathrm{~mol} \%$ (HPLC).

\section{Acknowledgements}

We thank Dr Peter Schumann and Dr Cathrin Spröer from the DSMZ for custom analysis of $\mathrm{G}+\mathrm{C}$ content and DNA-DNA hybridization and discussion.

\section{References}

Campbell, L. L. \& Postgate, J. R. (1965). Classification of the sporeforming sulfate-reducing bacteria. Bacteriol Rev 29, 359-363.

Cato, E. P., George, W. L. \& Finegold, S. M. (1986). Genus Clostridium Prazmowski 1880, 23 ${ }^{\mathrm{AL}}$. In Bergey's Manual of Systematic Bacteriology, vol. 2, pp. 1141-1200. Edited by P. H. A. Sneath, N. S. Mair, M. E. Sharpe \& J. G. Holt. Baltimore: Williams \& Wilkins. 
Collins, M. D., Lawson, P. A., Willems, A., Cordoba, J. J., FernandezGarayzabal, J., Garcia, P., Cai, J., Hippe, H. \& Farrow, J. A. E. (1994). The phylogeny of the genus Clostridium: proposal of five new genera and eleven new species combinations. Int J Syst Bacteriol 44, 812-826.

Elsden, S. R. \& Hilton, M. G. (1979). Amino acid utilization patterns in clostridial taxonomy. Arch Microbiol 123, 137-141.

Escoffier, S., Ollivier, B., Le Mer, J., Garcin, J. \& Roger, P. A. (1998). Evidence and quantification of thiosulfate-reducers unable to reduce sulfate in rice-field soils. Eur J Soil Biol 34, 69-74.

Escoffier, S., Cayol, J.-L., Ollivier, B., Patel, B. K. C., Fardeau, M.-L., Thomas, P. \& Roger, P. A. (2001). Identification of thiosulfate- and sulfur-reducing bacteria unable to reduce sulfate in ricefield soils. Eur $J$ Soil Biol 37, 145-156.

Hernández-Eugenio, G., Fardeau, M.-L., Cayol, J.-L., Patel, B. K. C., Thomas, P., Macarie, H., Garcia, J.-L. \& Ollivier, B. (2002). Clostridium thiosulfatireducens sp. nov., a proteolytic, thiosulfate- and sulfurreducing bacterium isolated from an upflow anaerobic sludge blanket (UASB) reactor. Int J Syst Evol Microbiol 52, 1461-1468.

Hippe, H., Andreesen, J. R. \& Gottschalk, G. (1992). The genus Clostridium - nonmedical. In The Prokaryotes, 2nd edn, vol. 2, pp. 1800-1866. Edited by A. Balows, H. G. Trüper, M. Dworkin, W. Harder \& K. H. Schleifer. New York: Springer.

Hollaus, F. \& Sleytr, U. (1972). On the taxonomy and fine structure of some hyperthermophilic saccharolytic clostridia. Arch Microbiol 86, 129-146.

Lee, Y.-E., Jain, M. K., Lee, C., Lowe, S. E. \& Zeikus, J. G. (1993). Taxonomic distinction of saccharolytic thermophilic anaerobes: description of Thermoanaerobacterium xylanolyticum gen. nov., sp. nov., and Thermoanaerobacterium saccharolyticum gen. nov., sp. nov.; reclassification of Thermoanaerobium brockii, Clostridium thermosulfurogenes, and Clostridium thermohydrosulfuricum E100-69 as Thermoanaerobacter brockii comb. nov., Thermoanaerobacterium thermosulfurigenes comb. nov., and Thermoanaerobacter thermohy- drosulfuricus comb. nov., respectively; and transfer of Clostridium thermohydrosulfuricum $39 \mathrm{E}$ to Thermoanaerobacter ethanolicus. Int J Syst Bacteriol 43, 41-51.

Mechichi, T., Fardeau, M.-L., Labat, M., Garcia, J.-L., Verhé, F. \& Patel, B. K. C. (2000). Clostridium peptidivorans sp. nov., a peptidefermenting bacterium from an olive mill wastewater treatment digester. Int J Syst Evol Microbiol 50, 1259-1264.

Obst, M., Krug, A., Luftmann, H. \& Steinbüchel, A. (2005). Degradation of cyanophycin by Sedimentibacter hongkongensis strain $\mathrm{KI}$ and Citrobacter amalonaticus strain G isolated from an anaerobic bacterial consortium. Appl Environ Microbiol 71, 3642-3652.

Purushothaman, D., Balasundaram, C. S. \& Gunasekaran, S. (1981). Nitrogen fixation in the rhizosphere of rice. Proc Indian Natl Sci Acad B (Biol Sci) 47, 242-247.

Sallam, A. \& Steinbüchel, A. (2008). Anaerobic and aerobic degradation of cyanophycin by the denitrifying bacterium Pseudomonas alcaligenes strain DIP1 and the role of three other coisolates in a mixed bacterial consortium. Appl Environ Microbiol 74, 3434-3443.

Schink, B. \& Zeikus, J. G. (1983). Clostridium thermosulfurogenes sp. nov., a new thermophile that produces elemental sulphur from thiosulphate. J Gen Microbiol 129, 1149-1158.

Simon, R. D. \& Weathers, P. (1976). Determination of the structure of the novel polypeptide containing aspartic acid and arginine which is found in cyanobacteria. Biochim Biophys Acta 420, 165-176.

Stackebrandt, E. \& Rainey, F. A. (1997). Phylogenetic relationships. In The Clostridia: Molecular Biology and Pathogenesis, pp. 3-19. Edited by J. I. Rood, B. A. McClane, J. G. Songer \& R. W. Titball. New York: Academic Press.

Thabet, O. B. D., Fardeau, M. L., Joulian, C., Thomas, P., Hamdi, M., Garcia, J. L. \& Ollivier, B. (2004). Clostridium tunisiense sp. nov., a new proteolytic, sulfur-reducing bacterium isolated from an olive mill wastewater contaminated by phosphogypse. Anaerobe 10, 185-190. 